\title{
乾燥破壊現象における 亀裂パターン形成の数值解析
}

\author{
廣部 紗也子 ${ }^{1} \cdot$ 小國 健二 $^{2}$ \\ 1学生員 慶應義塾大学大学院 理工学研究科 開放環境科学専攻（ $\mathrm{T} 223-8522$ 神奈川県横浜市港北区日吉 3-14-1) \\ E-mail: s.hirobe@keio.jp \\ 2 正会員 慶應義塾大学教授 理工学部 システムデザイン工学科（† 223-8522 神奈川県横浜市港北区日吉 3-14-1） \\ E-mail: oguni@sd.keio.ac.jp
}

\begin{abstract}
乾燥破壊現象における亀裂の特徵的な幾何形状の支配法則は未だ解明されていない，既存研究は，乾燥に伴う 不均一な水分分布が亀裂パターン形成の重要な役割を担うという直観に反し, 解析領域内での一様な水分分布 を前提とするか, 水分移動・変位場の発生・破壊の擬似的な連成解析に留まっていた. 本論文では, 乾燥破壊に おける亀裂パターン形成の問題に対し, i) 乾燥に伴う水分移動と体積変化, ii) 不均一な体積収縮を反映しつつ, つりあい状態を満たす変位場の発生, iii) 亀裂の形成, 全ての連成モデルを提案する. 粒子離散化有限要素法に よる固体連続体の変形及び破壊の過程の解析と，破壊面の形状を反映させた拡散係数をもつ拡散方程式の有限 要素解析の弱連成解析を行うことで, 乾燥破壊現象に特徵的な亀裂パターンとその幾何形状の変化を再現する.
\end{abstract}

Key Words: desiccation cracks, pattern formation, coupled model, PDS-FEM

\section{1.はじめに}

濡れた土や粉体が乾燥する過程で発生する亀裂は乾 燥亀裂とよばれ，水の干上がった田んぼや乾燥した地 域の地面などで容易に観察することができる．土木材 料においては，コンクリートの乾燥収縮に伴うクラッ クが，その顕著な例である。 また，乾燥亀裂は地盤の 強度や，透水性，圧縮性に影響を与える，そのため，乾 燥亀裂の発生及び進展のメカニズムを明らかにするこ とは, ダムや堤防などの土構造物や, 廃棄物処理に使 用される粘土ライナーの性能低下を予測し, 安定性を 確保する上で非常に重要である11,2).

現象の観察の容易さの一方で, 乾燥亀裂がもつ特徵 的な幾何形状がいかにして決まるのかという単純な問 題は，1 世紀以上におよぶ知見をもってしても未だ解明 されていない, 乾燥破壊の亀裂パターンは, 網目状構 造をもち，亀裂に囲まれたセルが特定のサイズの多角 形になる，という普遍的な特徵をもつ. 特定の粉体 - 水 混合物に着目した場合, セルのサイズと形状が系のサ イズと境界条件（層厚や拘束条件，蒸発速度など）に対 し，一定の規則性を伴って変化することは，1917 年の Kindle $^{3)}$ の実験を始めとし多くの実験によって確かめら れている4) 9). 乾燥亀裂は様々な材料で確認されてお り，セルのサイズ・形状・網目構造のトポロジーは材料 や条件によって異なるが, 網目状の構造を持つ亀裂群 が特定のサイズの多角形を形成するという共通の特徵 は保たれている。この事実は, 乾燥破壞現象における
亀裂パターン形成の背後に存在する, 材料によらない 共通の支配法則を示唆している.

乾燥破壊現象に関する実験的研究は, 乾燥過程にお ける試料内部の物理量変化のミクロスケールでの測定 の困難さを踏まえて, 系のサイズおよび境界条件と亀 裂の幾何形状との間の関係や, 試料からの水分の蒸発 量と亀裂本数との関係などについての実験事実の収集 と, これに基づく現象論的な物理モデルの構築を目的 としていた.(これらの研究のうち, 特に詳細なデータ を示しているものは 1960 年の Corte and Higashi ${ }^{10)}$ のレ ポートである)．この方針に基づく研究は，近年に至る まで多くの条件と物質について網羅的に行われている. しかし, 測定できる物理量は, 系のサイズ, 境界条件, 試料全体での含水量変化など, マクロスケールで平均 化された值のみである. 亀裂の進展方向, 枝分かれ, 交 差角などは, 亀裂先端近傍のミクロスケールでの物理 場によって決定されることを考えると，マクロスケー ルでの物理量の平均值とマクロスケールでの亀裂の特 徵量との関係に基づく現象論的物理モデルを用いて乾 燥破壞現象を説明することは難しいと結論付けざるを 得ない.これが, 著者らが数值解析的アプローチを選 択する理由である。

乾燥破壊の亀裂パターン形成において, 乾燥に伴う 水分移動による不均一な水分分布が重要な役割を担う ことは直観的に理解できる. しかし，この直観に反し て, 一様な水分分布を前提と寸る研究が, 乾燥破壊亀 裂の数值解析のメインストリームを形成してきた. 
この流れの始まりは, Vogel et al. ${ }^{11)}$ によるばねネッ トワークモデルである。このモデルでは, ばねの自然長 を短くすることによって水分の蒸発に伴う体積収縮を 表現している，破壞は格子状に配置したばねの切断に より表現され，ばねの性質，ばねの結節点の動きやす さ，ばねの配置，にそれぞればらつきを与えることで， 材料強度, 変形場, 境界条件のばらつきがモデルの中 に導入されている。このモデルは, パラメータの適切 なチューニングによって, 網目状の亀裂パターンを作 り出すことは出来るが, セルのサイズや形状は, 実際 に観察される乾燥亀裂パターンとは大きく異なる。つ まり，このモデルは，乾燥破壊現象を念頭に置いては いるが，乾燥破壊とは全く異なるセルラーオートマト ンと位置づけられる.

Sima et al. ${ }^{12)}$ では, DEM を用いて, 水分の蒸発の影 響を粒子の体積収縮，粒子間のばね定数，粒子間のば ね強度に反映させることにより, ばねネットワークモ デルを粘土の乾燥亀裂パターン形成の問題に近づける 試みがなされている，網目状の亀裂パターンや，層厚 や拘束条件に応じてのセルサイズの変化など, 定性的 な傾向の再現には成功しているが，亀裂の階層構造や 乾燥の進行に伴う亀裂数の増加などの傾向は捉えられ ていない.

Sánchez et al. ${ }^{13)}$ では，均一な材料定数を持つ四面体ソ リッド要素とその要素境界に破壊を許すジョイント要 素を埋め込んだ有限要素モデルに, 水分の蒸発の影響 を四面体ソリッド要素の体積収縮として与えて, 乾燥 破壞の解析を行っている。この解析では, 乾燥亀裂パ ターンの形状, セルサイズ, およびこれらの層厚依存 性などを比較的良好に再現できるケースもあるが，実 験で観測される亀裂パターンから大きく外れる場合も ある. 良好に再現できる例は，ほぼ 2 次元問題と見な すことの出来る薄層試験体に限定されている.

以上のように, 乾燥に伴う水分移動による不均一な 水分分布を無視した数值解析的アプローチの研究は, 材 料の構成則の複雑化により, 亀裂パターンそのものの 複雑さや, 亀裂パターンと境界条件との関係の複雑さ を説明しようとする試みであると位置づけられる。し かし, 乾燥破壊の亀裂パターン形成が, i) 乾燥に伴う 水分移動と体積変化, ii) 不均一な体積收縮を反映しつ つ,つりあい状態を満たす変位場の発生, iii) 亀裂の形 成，の連成現象であることはほぼ自明である.

Peron et al. ${ }^{14)}$ は, 1 次元的乾燥亀裂パターンの再現を 目的とし, 水分移動に伴う体積收縮と变位場の問題を連 成させた FEM 解析を行っている. この連成解析から得 られる応力分布の傾向を反映する粒子径収縮の分布を DEM に挿入して, 1 次元的乾燥亀裂が試験体表面から 底面へ進展する様子を再現しているが，亀裂パターン
の再現には至っていない．また, Musielak and Śliwa ${ }^{15)}$ も水分分布の変化は考慮しているが，変形と破壊に関 しては簡易的なばねネットワークモデルを用いており, 固体連続体の変形・破壞を表現できておらず，これも亀 裂パターンの再現には至っていない. 両者の失敗の理 由は, 解析モデルが拡散・応力連成解析と破壊解析と の擬似的な連成解析モデルにとどまっているためであ ると考えられる。

以上を踏まえ, 本論文では, 乾燥破壊における亀裂 パターン形成の問題に対して, i) 乾燥に伴う水分移動と 体積変化, ii) 不均一な体積収縮を反映しつつ, つりあ い状態を満たす変位場の発生, iii) 亀裂の形成, の全て を連成させたモデルを提案する. 具体的には, 粒子離散 化有限要素法 (PDS-FEM: Particle Discretization Scheme Finite Element Method） 16),17) による固体連続体の変形お よび破壊の過程の解析と, 破壊面の形状を反映させた 拡散係数をもつ拡散方程式の有限要素解析の弱連成解 析を行うことで, 乾燥破壊現象に特徽的な亀裂パター ンとその幾何形状の変化を再現する.

\section{2. 炭酸カルシウムを用いた乾燥実験}

乾燥亀裂パターンに対する層厚の影響の観察および 数值解析におけるパラメータの設定を目的とした, 水 一炭酸カルシウム混合物の乾燥実験を行った. 実験の 概要は以下の通りである。まず体積含水率 $72 \%$ の炭酸 カルシウム懸濁液を用意し, 上面のみが開放された幅 $100 \mathrm{~mm} \times$ 奥行 $100 \mathrm{~mm} \times$ 深さ $50 \mathrm{~mm}$ のアクリル容器 に注いだものを試験体とした。このとき炭酸カルシウ ムは飽和状態にある。しばらく静置すると表面に水分 層ができるため, 水分層を除いた層の厚さが設定した い試験体厚さになるよう懸濁液の分量を調整した。例 えば, 設定する層厚が $10 \mathrm{~mm}$ の場合, 必要な懸濁液の 重さは $152 \mathrm{~g}$ であった. また, 蒸発が進み水分層がなく なる時点の平均体積含水率は $56.0 \%$ であった. 試験体 の層厚は $5 \mathrm{~mm}, 10 \mathrm{~mm}, 20 \mathrm{~mm}, 30 \mathrm{~mm} の 4$ 種類を用 意し, 室温 $20^{\circ} \mathrm{C}$, 相対湿度 $50 \%$ の一定值に保たれた実 験室に静置し, 乾燥させた. 試験体全体の含水量が減 少し, 試験体表面からの水の蒸発がなくなると乾燥過 程は終了する. 時間ごとの試験体の質量減少量と, 亀 裂発生時および亀裂進展終了時の平均体積含水率を測 定した.

各層厚における, 試験体上面の最終的な亀裂を図$\mathbf{1}$ に, 層厚 $10 \mathrm{~mm}$ における亀裂進展の様子と時間ごと の平均体積含水率の変化を図-2 と図-3にそれぞれ示す. 試験体の体積含水率の減少量がほぼゼロになる（乾燥 が終了する）よりも前に, 亀裂進展は終了した. 亀裂発 生時と亀裂進展終了時の平均体積含水率はどの層厚にお 

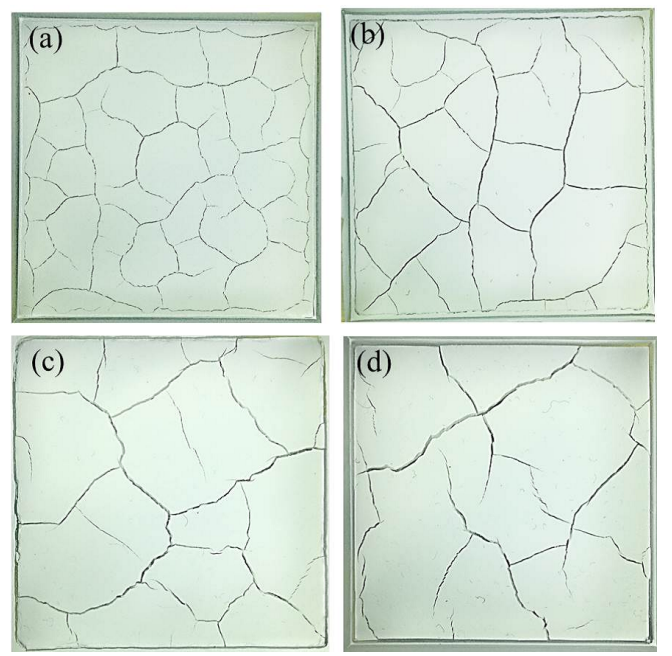

図-1 乾燥実験の最終的な亀裂パターン 層厚は (a) $5 \mathrm{~mm} \mathrm{(b)} 10 \mathrm{~mm}$ (c) $20 \mathrm{~mm}$ (d) $30 \mathrm{~mm}$
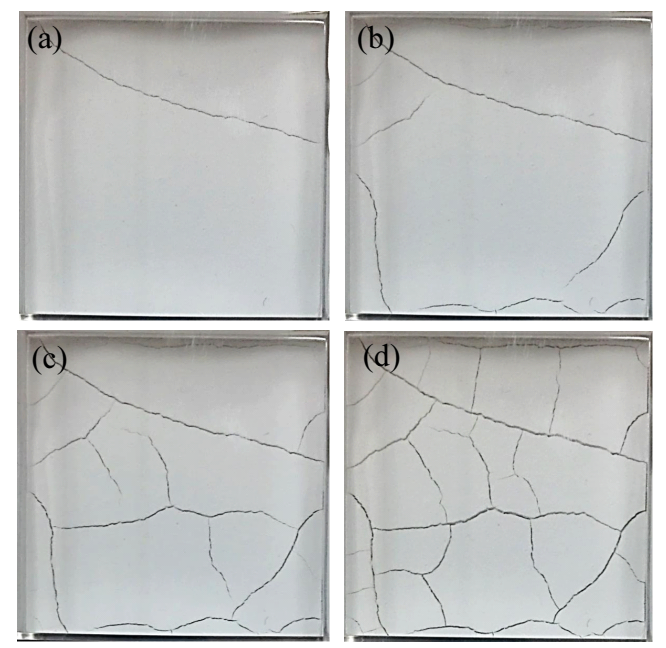

図-2 乾燥実験における亀裂進展（層厚 $10 \mathrm{~mm}$ の場合）

(a) 1 本目の亀裂形成時

(b) サイズが大きなセルの形成時

(c) セルの分割が進んでいる状態

(d)さらにセルの分割が進んだ状態

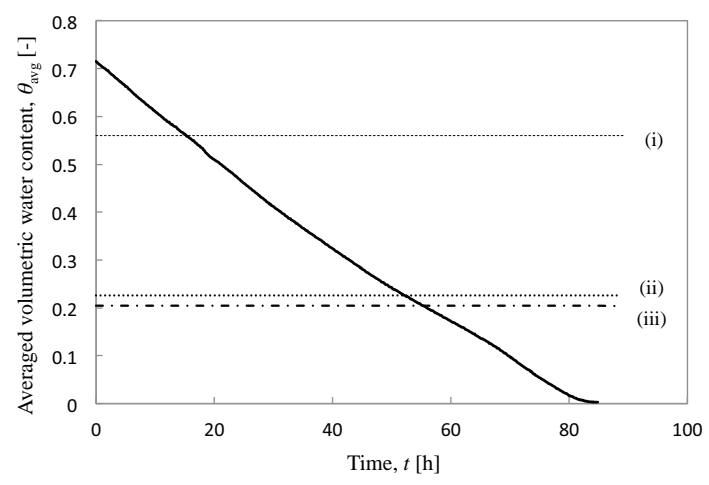

図-3 平均体積含水率の変化（層厚 $10 \mathrm{~mm}$ の場合） (i) 試験体表面の水分層がなくなった時点 (ii) 亀裂発生時 (iii) 亀裂進展終了時
土木学会論文集A2 (応用力学), Vol. 72, No. 1, 38-48, 2016.

いても，それぞれおよそ $22 \%$ と $20 \%$ であった. 図-1 か らは, 容器との癒着および摩擦の影響を大きく受ける 境界付近の一部のセルを除き, 各層厚で観察されたセ ルはおよその面積が一致していることが分かる。また， 各層厚におけるセルの平均的な面積は, 層厚の増加に伴 い増加していることが確認できるが， $20 \mathrm{~mm}$ と $30 \mathrm{~mm}$ ではその差はわずかであった。

図-2に示寸ように，初めに長い亀裂が進展し，その 後, 亀裂によって囲まれたセルのうち, 大きいセルを 分割するように新たな亀裂が発生した。この亀裂進展 の特徴はどの層厚においても観察された.

図-3 は，少なくとも亀裂が進展している間は，蒸発 速度が一定であることを示している，粉体-水混合物の 蒸発速度は, 大気の蒸発能を満たす可能蒸発速度で蒸 発が進行する「乾燥の第 1 段階」, 粉体-水混合物の水 分供給能力が大気の蒸発速度を満たせなくなり, 蒸発 速度が減少する「乾燥の第 2 段階」, さらに低い蒸発速 度を維持する「乾燥の第 3 段階」に分けられる ${ }^{18)}$. 蒸 発速度が一定であることから, 亀裂進展中の蒸発は常 に「乾燥の第 1 段階」にあったことが分かる.

\section{3. 乾燥破壊現象の数理モデル}

本論文では,「乾燥に伴う水分移動と収縮」と「収縮 に伴う変形と破壞」との連成を固体連続体力学の枠組 みで記述する. 具体的には, 連続体力学に基づく $2 つ$ の物理現象の支配方程式と, それら 2 つ支配方程式 の連成の仕組みを導入する. 水分移動に伴う体積変化 を線形弾性体の変形の問題に組み込んで, 乾燥と変形 との連成を図る. 変形の進行に伴う破壊はPDS-FEM で 扱い, 水分移動に対する亀裂の影響を, (i) 亀裂面から の蒸発, (ii) 亀裂面をまたいで通過する流束の制限, と して表現することにより, 破壊と乾燥とを連成させる.

\section{(1) 連成系の設定}

等温条件下の不飽和土中における非定常流れの水分 量はリチャーズ式によって表現される. 水分量表記の リチャーズ式は,

$$
\frac{\partial \theta}{\partial t}=\nabla(D(\theta) \nabla \theta)+\frac{\partial K(\theta)}{\partial z}
$$

のように 2 階の非線形偏微分方程式で表される。ここ で $\theta$ は体積含水率, $t$ は時間, $K(\theta)$ は不飽和透水係数, $D(\theta)$ は水分拡散関数を表す. $z$ 軸を鉛直下向きの座標 軸とすると, 右辺第 2 項は重力の影響を表現する項と 見なすことができる. 水分拡散関数は, 体積含水率の 増加関数となる. 試験体表面からの「乾燥の第 2 段階」 における蒸発速度の低下は, 体積含水率が低く水分拡 散関数の值が小さい表層部分の増加により, 水分供給 能力が低下寸ることに起因する. 前節で示した炭酸力 
ルシウムの乾燥実験における亀裂進展過程は, 温度・湿 度一定で,「乾燥の第 1 段階」にあることから，表層部 の水分拡散関数は, 十分大きいと考えられる.これは, 試験体が比較的薄く, 水分分布には深さ方向でそれほ ど大きな変化は生じなかったためだと推察される．この ことから, 本論文の炭酸カルシウムの乾燥実験に基づ く数值解析の範囲では, 水分拡散関数が体積含水率に よらず一定としても現象を再現するには十分と考えた. さらに，重力の影響を無視すると，リチャーズ式は，

$$
\frac{\partial \theta}{\partial t}=D \nabla^{2} \theta
$$

のように Fick の拡散方程式と同形の式となる.よって, 試料 $\Omega$ 内の水分が外気との境界面 $\Gamma^{(1)}$ から蒸発する場 合， $\Omega$ 内の水分量分布は,

$$
\begin{cases}\dot{\theta}=D \theta_{, i i} & \boldsymbol{x} \in \Omega \\ D \theta_{, i} n_{i}=-Q^{(1)}(\theta) & \boldsymbol{x} \text { on } \Gamma^{(1)} \\ \theta(\boldsymbol{x}, 0)=\bar{\theta}(\boldsymbol{x}) & \boldsymbol{x} \in \Omega\end{cases}
$$

で与えられる初期值境界值問題を解くことによって得 られる。ここで, 体積含水率 $\theta$ は位置 $\boldsymbol{x}$ と時間 $t$ の関 数であり, $Q^{(1)}(\theta)$ は $\Gamma^{(1)}$ からの蒸発に対応する水分フ ラックスを表す。なお式 $(3 \mathrm{a}, 3 \mathrm{~b}, 3 \mathrm{c})$ およびこれ以降，下 付き添字を用いて表記される式には総和規約を適用す る. 本論文では, 式 (3a) に従う液体水の移動のみを考 慮し, 水蒸気移動は考慮しない. また, 液体水の移動は 十分に遅いため, 摩擦の影響は無視できるものとする.

試料 $\Omega$ 内に発生した亀裂面 $\Gamma^{(2)}$ が水分移動に及ぼす 影響を，すでに述べたように， $\Gamma^{(2)}$ からの蒸発，およ び $\Gamma^{(2)}$ をまたいで通過する流束の制限，として水分移 動に関する初期值境界值問題に導入する． $\Gamma^{(2)}$ からの 蒸発は, 式 (3b) の Neumann 型境界条件に,

$$
D \theta_{, i} n_{i}=-Q^{(\alpha)}(\theta) \quad \boldsymbol{x} \in \Gamma^{(\alpha)}(\alpha=1,2)
$$

のように新たな境界 $\Gamma^{(2)}$ と， $\Gamma^{(2)}$ からの蒸発による水 分フラックス $Q^{(2)}(\theta)$ を導入して表現する.

$\Gamma^{(2)}$ をまたいで通過する流束の制限を，流束は亀裂 面で完全に遮断される, すなわち $\Gamma^{(2)}$ をまたいで通過 する流束をゼロとする，ことによって導入する.

図-4に示す正規直交座標系 $\boldsymbol{e}_{i}$ 上でのダルシー則を水 分量表記で記述すると

$$
J_{i}=-D \theta_{, i}
$$

となる. $J_{i}$ は $\boldsymbol{e}_{i}$ 座標系上での水分フラックスである. $J_{i}$ の亀裂面 $\Gamma^{(2)}$ への射影 $J_{i}^{c}$ は,

$$
P_{i j}=e_{i}^{\prime} \cdot e_{j}
$$

で定義される座標変換行列 $P_{i j}$ と,

$$
\bar{E}_{i j}= \begin{cases}1 & \text { if } i=j=1,2 \\ 0 & \text { otherwise }\end{cases}
$$

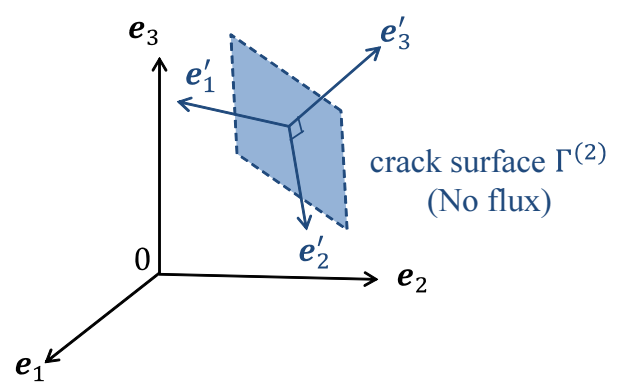

図-4 $P_{i j}$ によって変換された座標系

で定義される $\Gamma^{(2)}$ への射影行列 $\left(\boldsymbol{e}_{3}^{\prime}\right.$ は亀裂面 $\Gamma^{(2)}$ の単 位法線ベクトル）を用いて，

$$
J_{i}^{c}=P_{j i} \bar{E}_{j k} P_{k l} J_{l}
$$

と表される。これは，式 $(3 \mathrm{a}, 3 \mathrm{~b})$ に異方性をもつ拡散係 数を導入することと同義である. 以上により, 乾燥の 過程に破壊の影響を反映する仕組みが導入された。

均質な等方線形弾性体 $\Omega$ 微小変形問題に, 乾燥に よる収縮の影響を導入する。境界 $\partial \Omega$ に変位境界条件 $\bar{u}_{i}(\boldsymbol{x})$ が与えられたとき, 変位 $u_{i}(\boldsymbol{x})$ に関する境界值問 題は

$$
\begin{cases}\left(c_{i j k l} u_{k, l}(\boldsymbol{x})\right)_{, j}=0 & \boldsymbol{x} \in \Omega \\ u_{i}(\boldsymbol{x})=\bar{u}_{i}(\boldsymbol{x}) & \boldsymbol{x} \text { on } \partial \Omega\end{cases}
$$

となる。ここで, $c_{i j k l}$ は弾性係数を表す。この境界值 問題は, 以下の変分問題と等価である.

$$
\begin{gathered}
I\left(u_{i}(\boldsymbol{x})\right)=\int_{\Omega} e(\boldsymbol{\varepsilon}) d V \\
\text { Minimize } I\left(u_{i}(\boldsymbol{x})\right) \text { s.t. } u_{i}(\boldsymbol{x})=\bar{u}_{i}(\boldsymbol{x}) \\
\text { ここで, } e(\boldsymbol{\varepsilon}) \text { はひずみエネルギー密度で } \\
e(\boldsymbol{\varepsilon})=\frac{1}{2} \varepsilon_{i j}(\boldsymbol{x}) c_{i j k l} \varepsilon_{k l}(\boldsymbol{x}) \\
\varepsilon_{i j}=\frac{1}{2}\left(u_{i, j}+u_{j, i}\right)
\end{gathered}
$$$$
\text { Minimize } I\left(u_{i}(\boldsymbol{x})\right) \text { s.t. } u_{i}(\boldsymbol{x})=\bar{u}_{i}(\boldsymbol{x}) \text { on } \partial \Omega(10)
$$

である。

乾燥収縮の場合，全ひずみ $\varepsilon_{i j}$ は乾燥収縮ひずみ $\varepsilon_{i j}^{s}$ と弾性ひずみ $\varepsilon_{i j}^{m}$ から構成されていると考えることがで きる.このとき, 乾燥収縮ひずみは純粋に乾燥による 体積減少を示している。 これは全ひずみのゼロ点に対 するオフセットと位置付けられるため,

$$
\sigma_{i j}=c_{i j k l}\left(\varepsilon_{k l}-\varepsilon_{k l}^{s}\right)
$$

が成り立つ. したがって, 全く拘束を受けずに自由に 乾燥収縮できる場合には，全ひずみは乾燥収縮ひずみ と等しくなり $\left(\varepsilon_{i j}=\varepsilon_{i j}^{s}\right)$, 乾燥による体積減少のみで は, それに対応する内力としての応力は生じない. 何 らかの拘束により, $\varepsilon_{i j} \neq \varepsilon_{i j}^{s}$ となる場合にのみ, 乾燥 収縮ひずみ $\varepsilon_{i j}^{s}$ の発生が応力の発生を伴うことが可能と なる。 
乾燥破壊の問題では，乾燥に伴う体積収縮が何らか の拘束を受けて「自由収縮」から外れたときに生じる弾 性ひずみ $\left(\varepsilon_{i j}^{m}=\varepsilon_{i j}-\varepsilon_{i j}^{s}\right)$ が, 破壊を生じさせる原因 となる. 乾燥収縮の問題では解析対象となる領域には外 力による変形は加えられていないので, 平均的な全ひず み $\bar{\varepsilon}_{i j}$ と平均的な乾燥収縮ひずみ $\bar{\varepsilon}_{i j}^{s}$ は, $\bar{\varepsilon}_{i j}^{s} \leq \bar{\varepsilon}_{i j} \leq 0$ の関係にある. 平均的な乾燥収縮ひずみ $\bar{\varepsilon}_{i j}^{s}$ は負である ため, 平均的な応力場 $\bar{\sigma}_{i j}$ は, $\bar{\sigma}_{i j}=c_{i j k l}\left(\bar{\varepsilon}_{k l}-\bar{\varepsilon}_{k l}^{s}\right)$ よ り, 正となる.つまり, 乾燥破壊の問題での支配的な応 力場は引張応力場である. 物質の破壊強度の静水圧依 存性は，特に土質材料が圧縮応力下にある場合におい ては顕著に現れるが，引張応力が支配的となる場（本論 文が対象とする乾燥破壊の問題に対応する応力場）で

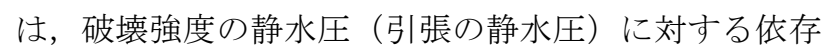
性はほとんど見られない. 土質材料であっても引張応 力下で破壊する際にはほぼ脆性的に破壊する。炭酸力 ルシウムペーストの乾燥破壞実験においても，ほぼ脆 性的な破壊が観察された。 以上より, 本研究では静水 圧（引張の静水圧）に依存しない引張破壊強度を用い た破壊規準を適用する.

式 (13) を式 (11) に適用寸ると, 汎関数 $I$ は

$$
I=\int_{\Omega} \frac{1}{2}\left(\varepsilon_{i j}-\varepsilon_{i j}^{s}\right) c_{i j k l}\left(\varepsilon_{k l}-\varepsilon_{k l}^{s}\right) d V
$$

と書きかえられる。このアプローチは, 粘土の乾燥収 縮の既存研究においてもしばしば適用されている6).

\section{(2) PDS-FEMによる乾燥・変形・破壊の連成}

PDS-FEM は変位場に対する粒子的な離散化を用いて, 固体連続体の変形および破壞の問題に関する境界值問 題を解く数值解析手法である. PDS-FEM では, 境界值 問題と等価な変分問題の汎関数 $I$ を数值的に評価する ために, 解析領域 $\Omega$ 内の点群 $\left\{\boldsymbol{x}^{\alpha}\right\}$ に対し一意に定ま る Voronoi 分割 $\left\{\Phi^{\alpha}\right\}$ と, その共役図形である Delaunay 分割 $\left\{\Psi^{\beta}\right\}$ にって, 変位場と応力場をそれぞれ離散化 する. 2 次元の場合の Delaunay 分割と Voronoi 分割を 図-5に示す. 3 次元領域においては, Delaunay ブロッ クは四面体となる。

関数の離散化の基底には, Voronoi ブロックと Delaunay ブロック上に立つ以下の特性関数を用いる.

$$
\begin{aligned}
& \phi^{\alpha}(\boldsymbol{x})= \begin{cases}1 & \left(\boldsymbol{x} \in \Phi^{\alpha}\right) \\
0 & \left(\boldsymbol{x} \notin \Phi^{\alpha}\right)\end{cases} \\
& \psi^{\beta}(\boldsymbol{x})= \begin{cases}1 & \left(\boldsymbol{x} \in \Psi^{\beta}\right) \\
0 & \left(\boldsymbol{x} \notin \Psi^{\beta}\right)\end{cases}
\end{aligned}
$$

つまり, 変位場は Voronoi ブロック $\left\{\Phi^{\alpha}\right\}$ で定義され る粒子が $\left\{\Phi^{\alpha}\right\}$ の点 $\left\{\boldsymbol{x}^{\alpha}\right\}$ と同じ並進運動をする「剛 体粒子群の並進運動の場」によって表され, 変位の勾 配に関する物理量（ひずみ, 応力）は Delaunay 四面体

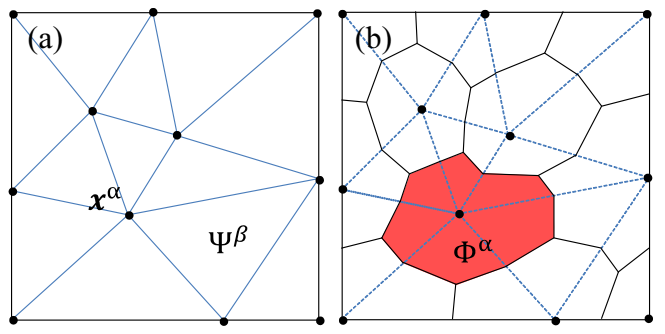

図-5 2 次元の場合の解析領域 $\Omega$ の離散化 (a) Delaunay 分割 $\Psi^{\beta}$ (b) Voronoi 分割 $\Phi^{\alpha}$

内部に生じる変位のギャップに基づいて平均化され，評 価される.

これらの特性関数を用いた基底によるひずみ場と応 力場の離散化は, 四面体一次要素における一様ひずみ 場，一様応力場に対応する. PDS-FEMでは，このよう な互いに重なり合わず不連続な特性関数を用いること によって, 破壞によって発生する不連続な変位場を, 簡 便に取り扱うことができる。この離散化手法を式 (14) に適用すると, 離散化された汎関数 $\hat{I}$ は,

$$
\hat{I}=\sum_{\beta=1}^{M} \frac{1}{2}\left(\varepsilon_{i j}^{\beta}-\varepsilon_{i j}^{s \beta}\right) c_{i j k l}^{\beta}\left(\varepsilon_{k l}^{\beta}-\varepsilon_{k l}^{s \beta}\right) \Psi^{\beta}
$$

となる. ここで, $M$ は, Delaunay ブロックの数で, $\Psi^{\beta}$ は $\beta$ 番目の Delaunay ブロックの体積である. 式(17)に おいて, 汎関数 $\hat{I}$ は, 各 Delaunay ブロック上で平均ひ ずみエネルギー密度を積分し, 解析領域全体で合計す ることによって数值的に評価される. PDS-FEM では, $\beta$ 番目の Delaunay ブロック内でのひずみは

$$
\varepsilon_{i j}^{\beta}=\sum_{\alpha=1}^{N} \frac{1}{2}\left(B_{j}^{\beta \alpha} u_{i}^{\alpha}+B_{i}^{\beta \alpha} u_{j}^{\alpha}\right)
$$

と定義される．ここで， $N$ は Voronoi ブロックの数で あり, $B_{i}^{\beta \alpha}$ は,

$$
\begin{aligned}
B_{i}^{\beta \alpha} & =\frac{1}{\Psi^{\beta}} \int_{\Psi^{\beta}} \phi_{i}^{\alpha}(\boldsymbol{x}) \psi^{\beta}(\boldsymbol{x}) d V \\
& =\frac{1}{\Psi^{\beta}} \int_{\partial \Psi^{\beta}} n_{i}^{\alpha}(\boldsymbol{x}) d S \\
& =\frac{1}{\Psi^{\beta}} \int_{\partial^{\alpha} \cap \Psi^{\beta}} n_{i}^{\alpha}(\boldsymbol{x}) d S
\end{aligned}
$$

である. 式 (19) 中では, $\Phi^{\alpha}$ 上の特性関数 $\phi^{\alpha}(\boldsymbol{x})$ の $x_{i}$ 方向の微分の $\Psi^{\beta}$ 上での体積分を, ガウスの発散定理と Voronoi ブロックの剛体変位の性質を用いて, $\partial \Phi^{\alpha} \cap \Psi^{\beta}$ 上での $\Phi^{\alpha}$ の外向き法線ベクトル $n_{i}^{\alpha}(\boldsymbol{x})$ の面積分に置 き換えている.

そして, 式 (19) の $B_{i}^{\beta \alpha}$ は, 通常の有限要素法の四 面体 1 次要素において離散化された変位とひずみの関 係を表す B マトリクスの成分と一致している，破壊は Voronoi ブロック間の相互作用が失われることであり, 物体の変形に対する亀裂の影響は， $B_{i}^{\beta \alpha}$ において破壊 が発生した Voronoi ブロック境界での変位ギャップが 
Delaunay 四面体での平均ひずみに及ぼす寄与を 0 にす ることで表現される。一方, 水分の移動に対する亀裂の 影響は, 亀裂の発生した Voronoi ブロック境界を式 (4) および図-4の $\Gamma^{(2)}$ とすることにより，水分移動の問題 に組み込まれる。

式(18)で表される変位とひずみの関係を，式(17)に 代入し, 変位 $u_{i}^{\alpha}$ に関寸る $\hat{I}$ の停留条件を求めると,

$$
\frac{\partial \hat{I}\left(u_{i}^{\alpha}\right)}{\partial u_{i}^{\alpha}}=0
$$

より, カのつりあい式

$$
\sum_{\gamma=1}^{N} K_{i k}^{\alpha \gamma} u_{k}^{\gamma}=f_{i}^{\alpha}
$$

が得られる。ここで,

$$
\begin{aligned}
K_{i k}^{\alpha \gamma} & =\sum_{\beta=1}^{M} B_{j}^{\beta \alpha} c_{i j k l}^{\beta} B_{l}^{\beta \gamma} \Psi^{\beta} \\
f_{k}^{\alpha} & =\sum_{\beta=1}^{M} \varepsilon_{i j}^{s \beta}\left(c_{i j k l}^{\beta} B_{l}^{\beta \alpha}\right) \Psi^{\beta}
\end{aligned}
$$

である．乾燥に伴う体積収縮の影響は, 式 (23) の $\varepsilon_{i j}^{s \beta}$ によって, つりあい式(21)に反映される.

乾燥と物体の変形とを連成させるためには, 乾燥収縮 ひずみ $\varepsilon_{i j}^{s \beta}$ と, 水分量との関係を組み込めば良い. PDSFEM では，ひずみの平均化領域を Delaunay 四面体上に とることから, Delaunay 四面体が水分量の減少によっ て等方的に乾燥収縮すると仮定し, Delaunay 四面体の 乾燥に伴う体積収縮ひずみから $\varepsilon_{i j}^{s \beta}$ を求めることができ る. 一方, 領域内の水分量分布は, 式 $(3 a, 3 b, 3 c)$ を四 面体一次要素による通常の有限要素法によって数值的 に解くことで求めることができる．この四面体一次要素 と PDS-FEM における Delaunay 四面体が一致している とき, 領域内の体積含水率はV Voronoi 分割 $\left\{\Phi^{\alpha}\right\}$ によっ て離散化されていると考えられるため, 時刻 $t$ における Delaunay 四面体の体積含水率は, Delaunay 四面体を構 成する 4 つの Voronoi ブロック上の体積含水率の平均で あると定義する。ここから求まる， $\beta$ 番目の Delaunay 四面体の体積含水率 $\theta^{\beta}(\boldsymbol{x}, t)$ と, 水密度 $\rho_{w}$ 之粉体の乾 燥密度 $\rho_{d}$ を用いて, 乾燥に伴う $\beta$ 番目の Delaunay 四 面体の体積収縮ひずみ $\varepsilon^{v \beta}$ は,

$$
\varepsilon^{v \beta}(\boldsymbol{x}, t)=\frac{1}{\alpha} \frac{\rho_{w}}{\rho_{d}}\left\{\theta^{\beta}(\boldsymbol{x}, t)-\theta^{\beta}(\boldsymbol{x}, 0)\right\}
$$

と表される.ここで $\alpha$ は水分収縮係数であり物質によっ て決まる，乾燥収縮ひずみは等方かつせん断成分をも たないので,

$$
\left\{\begin{array}{l}
\varepsilon_{11}^{s \beta}=\varepsilon_{22}^{s \beta}=\varepsilon_{33}^{s \beta}=\frac{1}{3} \varepsilon^{v \beta} \\
\varepsilon_{i j}^{s \beta}=0 \quad(i \neq j)
\end{array}\right.
$$

となる。

PDS-FEM において，亀裂面 $\Gamma^{(2)}$ は図-6に示すよう に Voronoi ブロックの境界で定義される，そのため, 物

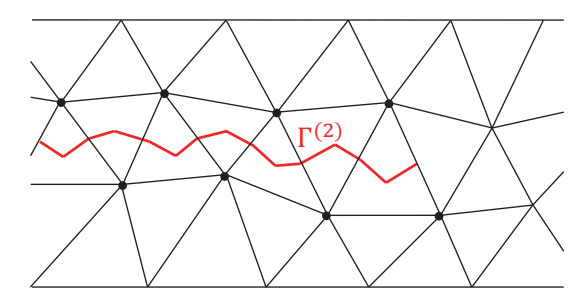

図-6 PDS-FEM における亀裂モデル

(a)

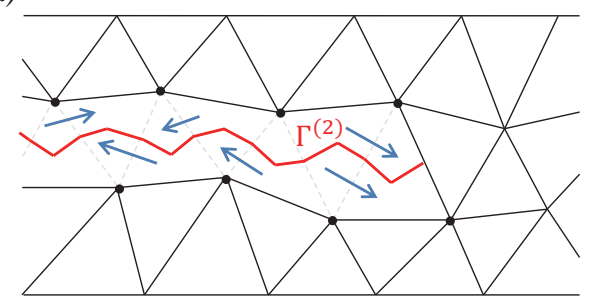

(b)

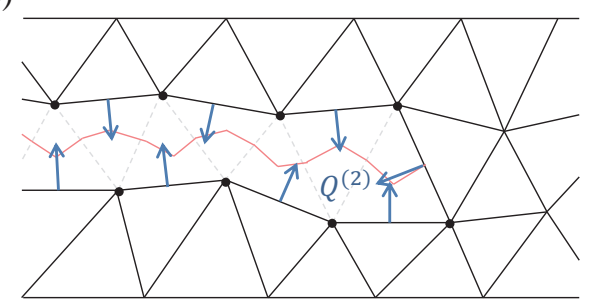

図-7 水の移動の問題における亀裂モデル

(a) $\Gamma^{(2)}$ の法線方向の流束のみが遮断される面

(b) 蒸発による流束 $Q^{(2)}(\theta)$ を与える面

体の変形の問題における亀裂は,「トラクションがゼロ となる亀裂面上に節点が配置されていない亀裂（blunt crack）」としてモデル化されている，一方，水の移動 の問題における亀裂は，図-7 に示寸ように，「法線方向 の流束が遮断される面 $\left(\Gamma^{(2)}\right) 」$, 「蒸発による流束 $Q^{(2)}(\theta)$ を与える面（破壞した Delaunay 四面体とそれ に隣接する Delaunay 四面体との境界面)」によりモデ ル化されている。これらは, 破壊面に新たな節点を配 置することなく簡便に亀裂を扱うために PDS-FEM お よび本研究における水の移動の問題に導入されている 「亀裂モデル」である.

\section{4. 乾燥破壊現象の数值解析}

拡散方程式で記述される水分移動と破壊は互いに時 間スケールが大きく異なる物理現象であることからここ れら $2 つ の$ 物理現象について弱連成解析を行った. 解 析対象は等方均質線形弾性体であると仮定し, 水分分 布と応力分布の時間発展を, 時間ステップ $\Delta t=0.1 \mathrm{~h}$ で 計算した。ただし, 亀裂発生後, 亀裂先端での応力場 が大きく変化するため, 全要素中最大のトラクション 
が引張強度の $97 \%$ 以上の場合には, 次の時間ステップ を $\Delta t=0.01 \mathrm{~h}$ と小さくした. 水分移動を表す初期值境 界值問題 (3a, 3b, 3c) の時間発展の解法には完全陰解法 (後退 Euler 法) を用い, 各時間ステップの中では, 時 間ステップを固定しながら 1 つずつ要素を破壊し，そ の都度，静的釣り合い状態を確保する，準静的破壊進 展解析を行った。破壊条件を満たす要素が無くなれば 次の時間ステップに進む. 実験の際の典型的な亀裂進 展の平均速度はたかだか $1[\mathrm{~cm} / \mathrm{h}]$ 程度であり, 準静的な 破壊進展解析の適用は妥当である.

また, 亀裂進展過程が「乾燥の第 1 段階」(蒸発速度 が一定）にあることから，いずれの解析においても，式 (4) における境界面 $\Gamma^{(1)}$ および亀裂面 $\Gamma^{(2)}$ からの蒸発 による水分フラックス $Q^{(1)}(\theta)$ と $Q^{(2)}(\theta)$ は体積含水率 $\theta$ に依らず一定とした，さらに，解析の開始時点で試料 全体は飽和しているとし, 初期体積含水率の分布は試 料内一様とした.

\section{(1) 1 次元的亀裂パターン}

Peron et al. ${ }^{19)}$ や Nahlawi and Kodikara ${ }^{20)}$ は，シルトを 用いた乾燥破壊実験において, 薄く細長い形状の水一シ ルト混合物に特定の境界条件を与え乾燥させると，平 行な 1 次元的亀裂パターンが試料上面で観察されるこ とを示した。 このときの亀裂はすべて長辺に対して垂 直な向きに進展する，上面において，亀裂と長辺によっ て囲まれた長方形領域をセルとみな寸と, 新たに発生 する亀裂は, 既に形成されているセルのうちサイズが 大きいセル内に発生することが観察されている. Peron et al. ${ }^{19)}$ の実験では成形した試料を基盤上に置くのみで, 側面は囲われていない。 また，基盤に切り込みを入れ ることで底面の長辺方向の収縮の夕拘束している。一 方, Nahlawi and Kodikara ${ }^{20)}$ の実験では細長い容器に混 合物を入れ, 底面は容器と試料の㾑着により, 長辺方 向，短辺方向共に収縮を拘束しているが，側面につい ては滑らかにすることで拘束を弱くしている．どちら の実験においても, 亀裂パターンの特徴は一致するが, 本研究では Peron et al. ${ }^{19)}$ の実験に基づき図-8のように 境界条件を設定した。具体的には,

- 底面にある節点は $z$ 方向と $x$ 方向の変位の夕拘束

・側面にある節点の変位は拘束しない

・上面と側面から蒸発が起こる（亀裂発生後は亀裂 面からも蒸発する)

となる。

また, モデルサイズや材料定数, 初期および亀裂進展 終了時の体積含水率についても Peron et al. ${ }^{19)}$ の実験值 を参考にした。これらを，表-1に示寸，亀裂の開口幅 は小さく, 亀裂面からの蒸発速度は試験体と外気の境 界面からの蒸発に比べ遅いと考えられることから, 亀

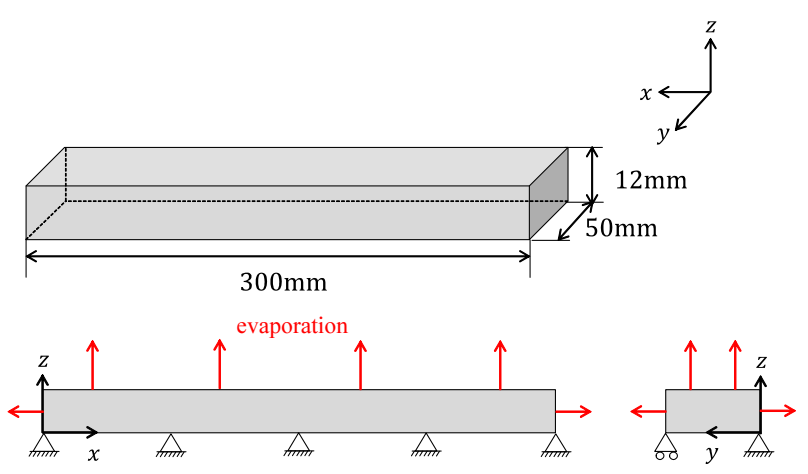

図-8 1 次元的亀裂パターンの数值解析における解析モデルと 境界条件

表-1 1 次元的亀裂パターンの数值解析におけるパラメータ

\begin{tabular}{l|c}
\hline 土乾燥密度 $\rho_{d}$ & $2.77 \times 10^{3} \mathrm{~kg} / \mathrm{m}^{3}$ \\
初期体積含水率 $\bar{\theta}$ & 0.721 \\
亀裂進展終了時体積含水率 $\theta^{f}$ & 0.324 \\
境界面の蒸発速度 $Q^{(1)}$ & $2.0 \times 10^{-4} \mathrm{~m} / \mathrm{h}$ \\
亀裂面の蒸発速度 $Q^{(2)}$ & $1.0 \times 10^{-4} \mathrm{~m} / \mathrm{h}$ \\
水分収縮係数 $\alpha$ & 0.64 \\
水分拡散係数 $D$ & $3.6 \times 10^{-6} \mathrm{~m}^{2} / \mathrm{h}$ \\
ポアソンン比 $\nu$ & 0.3 \\
ヤング率 $E$ & $5.0 \mathrm{MPa}$ \\
引張強度 $t_{c}$ & $0.45 \mathrm{MPa}$ \\
\hline
\end{tabular}

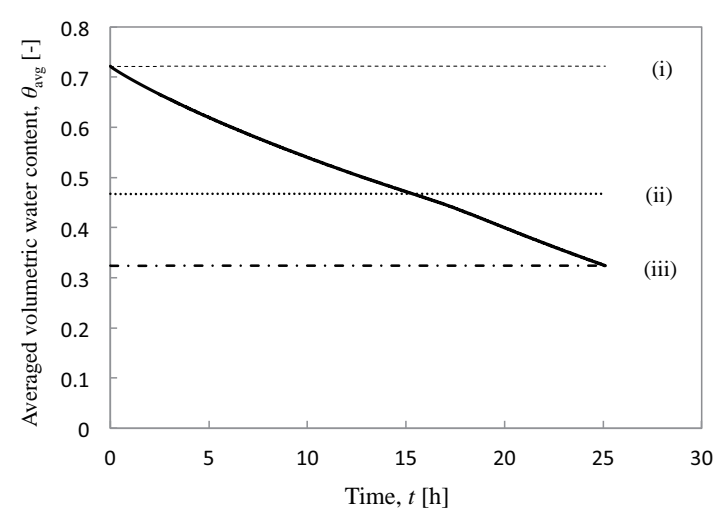

図-9 1 次元的亀裂パターンの数值解析における平均体積含水 率の変化 (i) 試験体表面の水分層がなくなった時点 (ii) 亀裂発生時 (iii) 亀裂進展終了時

裂面からの蒸発速度は境界面からの蒸発速度の $50 \%$ と した. 図-8 の解析対象について, 要素数 56,597, 節点 数 11,822 の四面体非構造メッシュによる有限要素モデ ルを作成した。

以上の条件を用いて, 1 次元的亀裂パターンの数值解 析を行った. 破壊は蒸発開始後 $15.37 \mathrm{~h}$ で発生し, $25.13 \mathrm{~h}$ には亀裂進展終了時の体積含水率となった。時間ごと の平均体積含水率 $\theta_{\text {avg }}$ の変化を図-9に, 最終的な亀裂 パターンの 3 次元的な様子を図-10, 上面の亀裂パター ンを図-11 にそれぞれ示寸. 図-9のように乾燥開始時か 


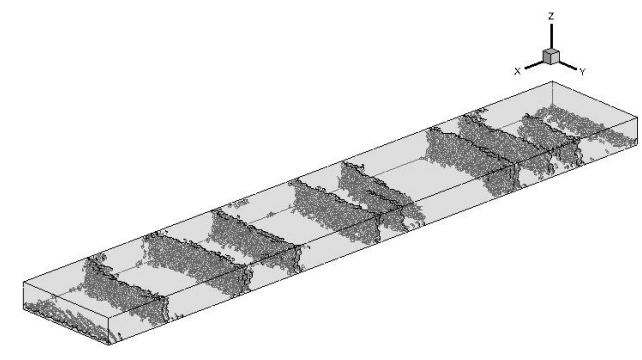

図-10 1 次元的亀裂パターンの数值解析結果

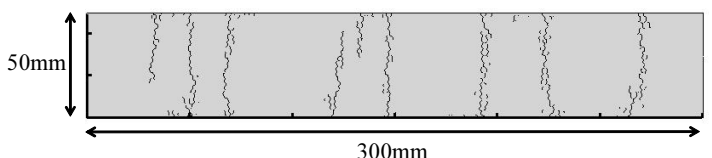

図-11 1 次元的亀裂パターンの数值解析における上面の亀裂 パターン

ら亀裂進展終了時の体積含水率になるまでの間，平均 体積含水率はほぼ一定の割合で減少した，図-10および 図-11には, 実験結果と同様, 長辺方向に垂直で互いに 平行な亀裂が発生し, 亀裂は試験体底面まで到達してい ることが示されている，また，図-10では，試験体底面 $(z=0 \mathrm{~mm})$ かつ長辺方向の両端 $(x=0 \mathrm{~mm}, 300 \mathrm{~mm})$ 付近に密集した亀裂群が発生していることが分かる。さ らに，実験で観察された亀裂の本数は，6本から 8 本で あり，その間隔は一部ばらつきがあるものの，多くは $20 \mathrm{~mm}$ から $60 \mathrm{~mm}$ の間であったのに対し ${ }^{19)}$ ，図-11に 示寸解析結果では, 亀裂本数 (短辺の半分以上の長さ まで進展している亀裂の本数) は 8 本であり, 得られ た 9 個の亀裂間隔は $15 \mathrm{~mm}$ から $55 \mathrm{~mm}$ であった。よっ て, 解析で得られた亀裂の幾何形状の特徽は, 亀裂の 本数, 亀裂面同士の間隔, 試験体底面の両端付近に密 集して現れる亀裂群まで, Peron et al. ${ }^{19)}$ による実験で観 察された現象に一致しているといえる.

\section{(2) 2 次元的亀裂パターンの数值解析}

次に, 炭酸カルシウムの乾燥実験から得られたパラ メータを元に数值解析を行い, 炭酸カルシウムの乾燥 実験で観察された網目状構造をもつ 2 次元的な亀裂パ ターンと層厚によるセルサイズの変化が再現可能であ ることを示す. 数值解析では実験と同様, 解析対象の層 厚 $H$ を $5 \mathrm{~mm}, 10 \mathrm{~mm}, 20 \mathrm{~mm}, 30 \mathrm{~mm}$ で変化させた. 実験では, 試料はアクリル容器と接している面が癒着 と摩擦によって拘束されていたとし，数值解析におけ る境界条件を図-12のように設定した。蒸発は，容器の 開口部（試料上面）および亀裂面からのみ起こるとす る. パラメータは，実験值から表-2のように設定した。 初期体積含水率は，実験において，表面の水分層がな
表-2 2 次元的亀裂パターンの数值解析におけるパラメータ

\begin{tabular}{l|c}
\hline 乾燥密度 $\rho_{d}$ & $800.0 \mathrm{~kg} / \mathrm{m}^{3}$ \\
初期体積含水率 $\bar{\theta}$ & 0.56 \\
亀裂進展終了時体積含水率 $\theta^{f}$ & 0.204 \\
境界面の蒸発速度 $Q^{(1)}$ & $8.8 \times 10^{-5} \mathrm{~m} / \mathrm{h}$ \\
亀裂面の丞発速度 $Q^{(2)}$ & $4.4 \times 10^{-5} \mathrm{~m} / \mathrm{h}$ \\
間隙率 $\phi$ & 0.87 \\
水分収縮係数 $\alpha$ & 0.69 \\
水分拡散係数 $D$ & $3.6 \times 10^{-6} \mathrm{~m}^{2} / \mathrm{h}$ \\
ポアソン比 $\nu$ & 0.3 \\
ヤング率 $E$ & $5.0 \mathrm{MPa}$ \\
引張強度 $t_{c}$ & $1.6 \mathrm{MPa}$ \\
\hline
\end{tabular}

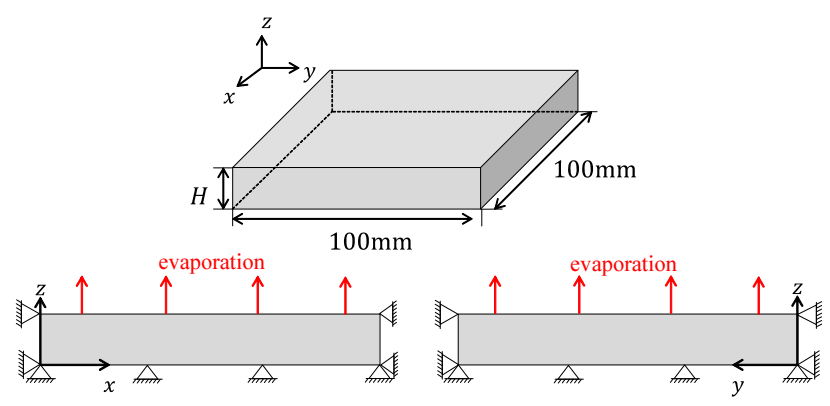

図-12 2 次元的亀裂パターンの数值解析における解 析モデルと境界条件

表-3 メッシュサイズ

\begin{tabular}{lcc}
\hline モデルサイズ $[\mathrm{mm}]$ & 要素数 & 節点数 \\
\hline $100 \times 100 \times 5$ & 253,930 & 50,355 \\
$100 \times 100 \times 10$ & 278,337 & 51,726 \\
$100 \times 100 \times 20$ & 309,509 & 55,304 \\
$100 \times 100 \times 30$ & 347,551 & 61,146 \\
\hline
\end{tabular}

くなった時点での平均体積含水率とした.

炭酸カルシウムのヤング率 $E$ と引張強度 $t_{c}$ は測定が 困難である. 本論文が対象とする乾燥収縮破壊の問題 ではヤング率 $E$ と引張強度 $t_{c}$ それぞれの值ではなく, $t_{c} / E$ 寸なわち, 試料を線形弾性体とみなした場合の破 断時の限界ひずみと, 水分収縮係数 $\alpha$ との比率が, 亀 裂生成のふるまいを支配している．水分収縮係数 $\alpha$ は, 間隙率などを用いて比較的高い信頼度を持つ值が得られ るため, 層厚 $10 \mathrm{~mm}$ の解析対象を用いて, $t_{c} / E=0.12$, 0.32，0.52 についてパラメトリックスタディを行った. その結果, $t_{c} / E=0.12$ では解析領域のほぼ全体にわたつ て細かな亀裂が発生し, $t_{c} / E=0.52$ では亀裂が十分に 進展しなかったことから， $t_{c} / E=0.32$ に定めた上で, 1 次元的亀裂パターンの数值解析における $E=5.0 \mathrm{MPa}$ を用いて $t_{c}$ の值を決定した。拡散係数の值は 1 次元的 亀裂パターンの数值解析と同じ值を用いた．各層厚に 対し，表-3 のような四面体非構造メッシュによる有限 

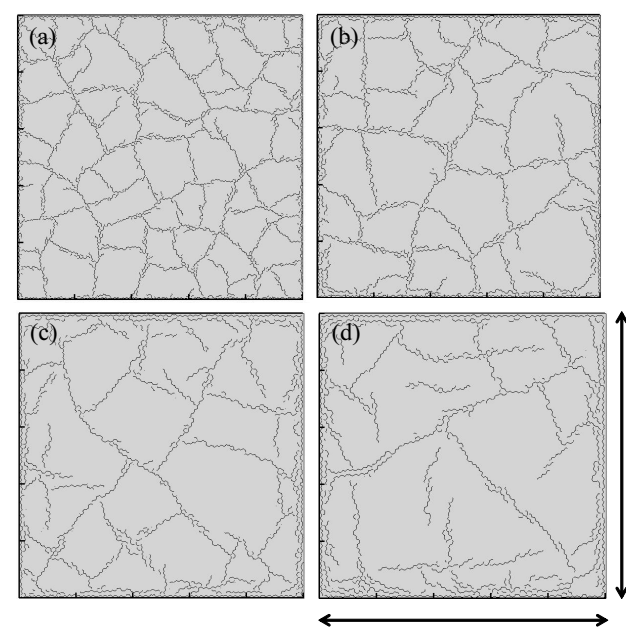

$100 \mathrm{~mm}$

図-13 2 次元的亀裂パターンの数値解析結果 層厚は (a) $5 \mathrm{~mm}$ (b) $10 \mathrm{~mm} \mathrm{(c)} 20 \mathrm{~mm}$ (d) $30 \mathrm{~mm}$
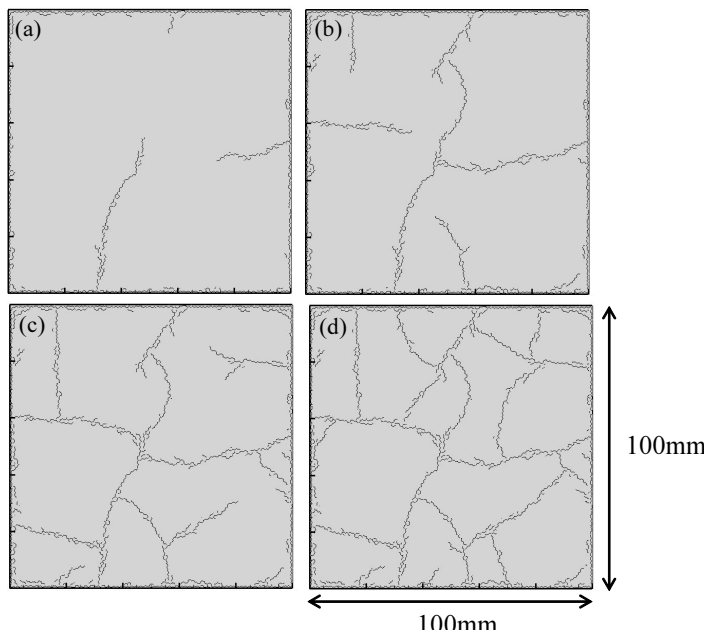

図-14 2 次元的亀裂パターンの解析における亀裂進展 (層厚 $10 \mathrm{~mm}$ の場合)

(a) 1 本目の亀裂形成時 $\left(\theta_{\text {avg }}=0.361\right)$

(b) サイズが大きなセルの形成時 $\left(\theta_{\mathrm{avg}}=0.335\right)$

(c) セルの分割が進んでいる状態 $\left(\theta_{\text {avg }}=0.309\right)$

(d) さらにセルの分割が進んだ状態 $\left(\theta_{\text {avg }}=0.285\right)$

要素モデルを作成し，解析を行った.

各層厚における試験体上面の最終的な亀裂パターンを

図-13 に，層厚 $10 \mathrm{~mm}$ における亀裂進展過程を図-14 に, それぞれ示す。図-13 から，いずれの層厚においても網 目状構造をもつ亀裂が形成され，層厚の増加に伴い平 均的なセル面積が大きくなっていることが分かる.こ の傾向は炭酸カルシウムの乾燥実験の結果と一致する. また, 図-14では, 炭酸カルシウムの乾燥実験の様子 (図-2) と同様，初めに長い亀裂が緩やかにカーブしな がら進展し，亀裂で囲まれたセルのうち，面積が大きい セル内に新たな亀裂が発生する様子が再現されている.

亀裂パターンに対するメッシュサイズの影響を調べ

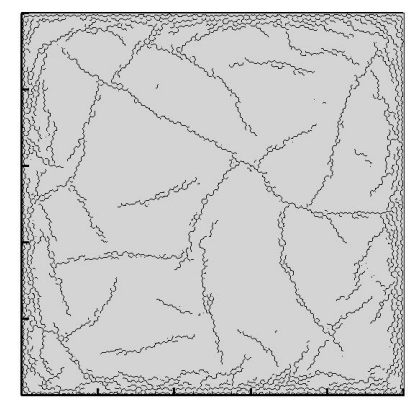

図-15 細かいメッシュ（要素数 $1,053,347$, 節点数 180,271) の層厚 $30 \mathrm{~mm}$ のモデルにおける上面の亀裂パターン
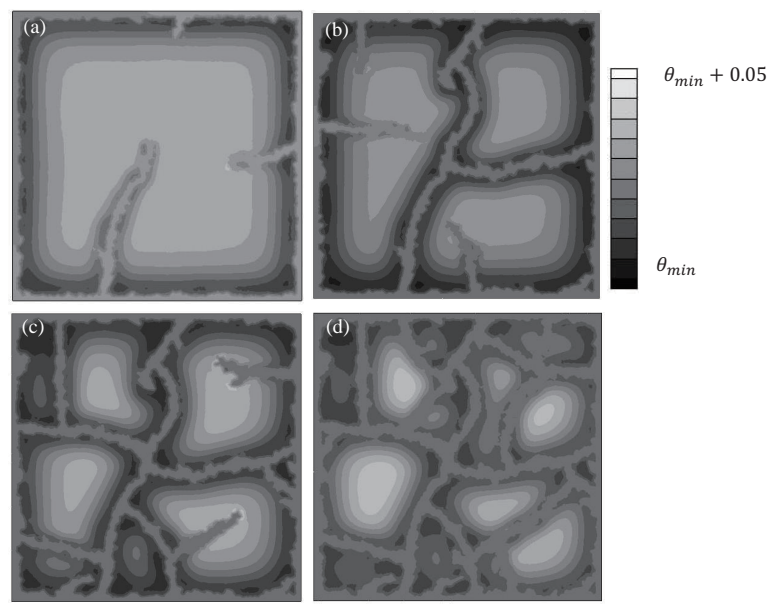

図-16 亀裂進展の各時点に対応した試験体表面での体積含水 率分布
(a) 1 本目の亀裂形成時 $\left(\theta_{\min }=0.30\right)$
(b) サイズが大きなセルの形成時 $\left(\theta_{\min }=0.29\right)$
(c) セルの分割が進んでいる状態 $\left(\theta_{\min }=0.27\right)$
(d) さらにセルの分割が進んだ状態 $\left(\theta_{\min }=0.25\right)$ $\theta_{\min }$ は各時点でのコンターの下限值である.

るため, 層厚 $30 \mathrm{~mm}$ について, 層厚 $5 \mathrm{~mm}$ のモデルの メッシュとほぼ同じ空間分解能をもつ有限要素モデル （要素数 $1,053,347$, 節点数 180,271）を作成し, 解析を 行った。この解析における上面の最終的な亀裂パター ンを，図-15に示す.

図-13 (d) と図-15を比較すると, メッシュを細かくし てもセルの面積や形状に大きな変化がないことが分か る.このことから, 亀裂パターンに対するメッシュサイ ズの影響はなく，表-3に示したメッシュサイズは，ど の層厚においても亀裂パターン形成の過程を再現する のに十分な空間分解能をもっていると言える.

図-14の各時点に対応した試験体表面での体積含水率 の分布を, 図-16に示す. 乾燥が進むにつれて体積含水 率 $\theta$ の平均が下がっていくため，ここではコンターの 幅を体積含水率の差で 0.05 に統一し， $\theta$ の減少に伴い コンターの下限值 $\theta_{\min }$ を変化させることで, 各時点で の分布の違いだけを抽出した。図-16から，各セルの中 心部では体積含水率が高くなり, セルの境界に向かって 


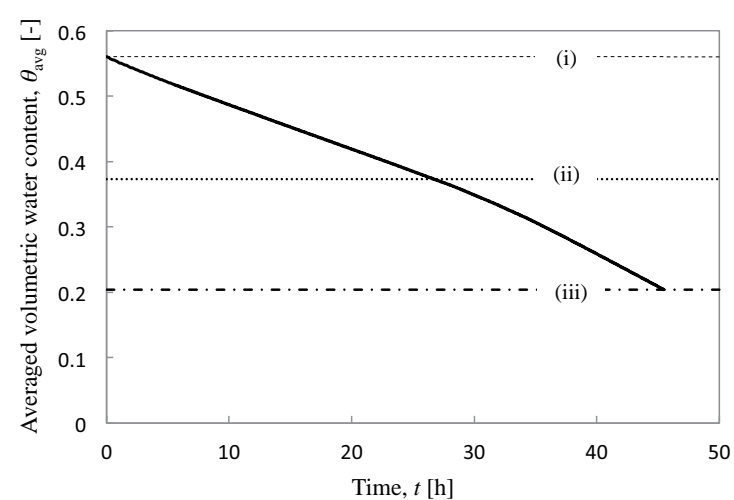

図-17 2 次元的亀裂パターンの数值解析における平均体積含 水率の変化（層厚 $10 \mathrm{~mm}$ の場合）

(i) 試験体表面の水分層がなくなった時点

(ii) 亀裂発生時 (iii) 亀裂進展終了時

減少していくのが分かる.この傾向はセルの分割に伴 いセルサイズが減少しても保たれている。このような 同心円状の体積含水率の分布によって, 各セル内での 収縮はセルの境界付近では大きく, 中心付近は小さく なる。そその結果，収縮が大きい境界付近では，同心円 状の分布の円周方向に引張応力が発生し, セルの境界 から中心に向かって新たな亀裂が進展する（図-16(b) (c)）と考えられる.

図-17に，層厚 $10 \mathrm{~mm}$ における平均体積含水率 $\theta_{\text {avg }}$ の変化を示す. 層厚 $5 \mathrm{~mm}, 10 \mathrm{~mm}, 20 \mathrm{~mm}, 30 \mathrm{~mm}$ につ いて, 亀裂進展終了時の体積含水率に至るまでにかかっ た時間は，それぞれ $25.71 \mathrm{~h} ， 45.48 \mathrm{~h} ， 73.49 \mathrm{~h} ， 94.81 \mathrm{~h}$ であった．図-3 と図-17を比較すると, 実験では試験 体表面の水分層がなくなった時点から亀裂進展終了時 の体積含水率に至るまでの時間は約 $40.2 \mathrm{~h}$ であったが, 数值解析では $45.48 \mathrm{~h}$ であり, 実験よりわずかに長かっ た.これは, 炭酸カルシウムの拡散係数に関するデータ が得られておらず, Peron et al. ${ }^{199}$ によるシルトの拡散係 数を用いたためであり, 実際の炭酸カルシウムの拡散 係数の值は本論文で用いた值より大きいと考えられる. また, 試験体表面に亀裂が発生する平均体積含水率は 数值解析結果の方が実験結果より大きくなった. 本質 的議論からは逸れるが，体積収縮率 $\alpha$ と $t_{c} / E$ に関する パラメータ・チューニングにより，この值を実験值に近 づけることは可能ではある。

以上より, 数值解析の結果は, パラメータ・チューニ ングにより修正可能な差違を残してはいるが，炭酸力 ルシウムの乾燥破壞実験で得られた

- 段階的な亀裂進展によるセル形成の過程

・セルの幾何形状とサイズ

・セルサイズと層厚との関係

と良好な一致を見せていると結論づけられる.

\section{5. 結論}

本論文では，乾燥破壞現象における亀裂パターン形 成の問題に対して, i) 乾燥に伴う水分移動と体積変化, ii) 不均一な体積収縮を反映しつつ,つりあい状態を満 た寸変位場の発生, iii) 亀裂の形成, を連成させたモデ ルを提案し, 実験結果と数值解析結果を比較すること で，モデルの妥当性を検証した．提案したモデルでは， 水分移動と固体連続体の変形及び破壊の支配方程式と して，それぞれ破壞面の形状を反映させた拡散係数を もつ拡散方程式と力のつり合い式を導入し, 有限要素法 と粒子離散化有限要素法を用いた弱連成解析を行った.

数值解析は, 1 次元的亀裂パターンと 2 次元的亀裂パ ターンに関して行い, ごちらの亀裂パターンに関して もセルの幾何形状と亀裂進展過程の特徵は, 実験結果 と良好に一致した。 また, 2 次元的亀裂パターンでは, 層厚に依存したセルサイズの変化も再現することがで きた. このことから, 提案したモデル及び手法は乾燥 破壞現象における刍裂パターン形成について, その特 徵的な幾何形状やセルサイズを再現するための基本的 な仕組みを有しているといえる。

一方で，本論文の数值解析に用いたパラメータのう ち, 水分拡散係数, 亀裂面からの蒸発速度, 物質の強 度を表す $t_{c} / E$ は, 実験から測定するのが困難であるこ とから，本論文で示した範囲外も含めた，より広いパ ラメータ空間でのパラメトリックスタディを行い, こ れらのパラメータが亀裂パターンに与える影響を検証 すると同時に, 実験・数值解析においてセルサイズに 関して, より精巧な定量的評価を今後行う必要がある.

本論文の提案モデルは, 亀裂の駆動力は乾燥過程で の不均一な水分分布に応じた不均一な体積収縮の等価 介在力であり, 乾燥・変形・破壊の 3 つの物理現象の連 成の中にあるという仮説を出発点としている. 実験と 数值解析結果の良好な一致は, この仮説がおおむ称妥 当であることを示唆している．このことを踏まえ，均 質な場の中に表れる特徴的な「長さスケール」である 「セルサイズ」の決定要因を突きとめ, 明示することが, 乾燥破壊現象の科学の枠組みにおける本論文の次のス テップである.また，拡散現象と物体の変形・破壊との 連成という意味では, 柱状節理構造も興味深い研究対 象である. 本論文の提案手法を, より厚みのある 3 次 元的な構造が生じや寸い解析対象に適用し, かつ水で はなく熱の拡散を考慮して, 柱状節理構造の形成過程 を解析することも，本論文の次のステップである.

謝辞： 本研究は JSPS 科研費 $15 \mathrm{H} 02262$ の助成を受け たものです. 


\section{参考文献}

1) Amarasiri, A. L., Kodikara, J. K. and Costa, S.: Numerical modelling of desiccation cracking, International Journal for Numerical and Analytical Methods in Geomechanics, Vol.35, pp.82-96, 2011.

2) Konrad, J. and Ayad, R.: Desiccation of a sensitive clay: field experimental observations, Canadian Geotechnical Journal, Vol.34, No.6, pp.929-942, 1997.

3) Kindle, E.: Some factors affecting the development of mudcracks, Journal of Geology, Vol.25, pp.135-144, 1917.

4) Tangand, C., Shi, B., Liu, C., Zhao, L. and Wang, B.: Influencing factors of geometrical structure of surface shrinkage cracks in clayey soils, Engineering Geology, Vol.101, No.34, pp.204-217, 2008.

5) Groisman, A. and Kaplan, E.: An experimental study of cracking induced by desiccation, Europhysics Letters, Vol.25, No.6, pp.415-420, 2006.

6) Peron, H., Laloui, L., Hueckel, T. and Hu, L.: Desiccation cracking of soils, European Journal of Environmental and Civil Engineering, Vol.13, No.7-8, pp.869-888, 2009.

7) Kodikara, J., Barbour, S. and Fredlund, D.: Desiccation cracking of soil layers, Unsaturated Soils for Asia. Proceedings of the Asian Conference on Unsaturated Soils, UNSAT-ASIA 2000, Singapore, 18-19 May, 2000, pp. 693698, 2000.

8) Rodríguez, R., Sánchez, M., Ledesman, A. and Lloret, A.: Experimental and numerical analysis of desiccation of mining waste, Canadian Geotechnical Journal, Vol.44, No.6, pp.644-658, 2007.

9) Bohn, S.: Hierarchical crack pattern as formed by successive domain divisions. II. form disordered to deterministic behavior, Physical Review E, Vol.71, No.4, pp.046215, 2005.

10) Corte, A. and Higashi, A.: Experimental research on desiccation cracks in soil, Technical report, U.S. Army Snow Ice and Permafrost Research Establishment, Illinois, USA, 1960.
11) Vogel, H., Hoffmann, H., Leopold, A. and Roth, K.: Studies of crack dynamics in clay soil II. a physically based model for crack formation, Geoderma, Vol.125, No.3-4, pp.213223, 2005.

12) Sima, J., Jiang, M. and Zhou, C.: Numerical simulation of desiccation cracking in a thin clay layer using $3 \mathrm{D}$ discrete element modeling, Computers and Geotechnics, Vol.56, pp.168-180, 2014.

13) Sánchez, M., Manzoli, O. and Guimarães, L.: Modeling 3-D desiccation soil crack networks using a mesh fragmentation technique, Computers and Geotechnics, Vol.62, pp.27-39, 2014.

14) Peron, H., Delenne, J., Laloui, L. and El Youssoufi, M.: Discrete element modelling of drying shrinkage and cracking of soils, Computers and Geotechnics, Vol.36, pp.61-69, 2008.

15) Musielak, G. and Śliwa, T.: Fracturing of clay during drying: Modelling and numerical simulation, Transport in Porous Media, Vol.95, pp.465-481, 2012.

16) Oguni, K., Wijerathne, M., Okinaka, T. and Hori, M.: Crack propagation analysis using PDS-FEM and comparison with fracture experiment, Mechanics of Materials, Vol.41, No.11, pp.1242-1252, 2009.

17）小國健二, 堀宗朗, 阪口秀: 破壊現象の解析に適した有限要 素法の提案, 土木学会論文集, No.766 / I-68, pp.203-217, 2004.

18) Campbell, G.(中野政詩, 東山勇監訳): パソコンで学ぶ土 の物理学: 自然環境管理の基礎, 鹿島出版会, 1987.

19) Peron, H., Hueckel, T., Laloui, L. and Hu, L.: Fundamentals of desiccation cracking of fine-grained soils: experimental characterisation and mechanisms identification, Canadian Geotechnical Journal, Vol.46, No.10, pp.1177-1201, 2009.

20) Nahlawi, H. and Kodikara, J.: Laboratory experiments on desiccation cracking of thin soil layers, Geotechnical and Geological Engineering, Vol.24, pp.1641-1664, 2006.

(2015. 11. 25 受付)

\section{NUMERICAL ANALYSIS OF PATTERN FORMATION IN DESICCATION CRACK PHENOMENON}

\section{Sayako HIROBE and Kenji OGUNI}

Cracks in desiccation crack phenomenon show a wide variety of geometric patterns. Our intuition tells that the major source of this wide variety is the coupling of water diffusion induced volume change, deformation, and fracture. In this paper, we propose a coupling model of i) change in water volume fraction due to desiccation, ii) deformation field corresponding to the inhomogeneous volume shrinkage, and iii) crack formation. Geometric patterns in desiccation crack phenomenon have been reproduced by weakly coupling the finite element analysis of water diffusion and analysis of deformation and failure by Particle Discretization Scheme Finite Element Method. 